\title{
Monipuolinen kiertomatka 1800-Iuvun alun Eurooppaan suomalaissäätyläisten matkassa
}

\author{
Heidi Pitkänen
}

Heli Rantala, Pikisaaresta Pariisiin. Suomalaismatkaajien kokemuksia 1800luvun Euroopassa, Gaudeamus, Helsinki, 2020, 306 s.

FT Heli Rantalan teos Pikisaaresta Pariisiin vie lukijansa antoisalle ja yllätykselliselle matkalle halki 1700-luvun lopun ja 1800-luvun alkupuoliskon Euroopan. Matkanteon vauhti sekä maisemat sopivat mainiosti niin aikakauden historiaa entuudestaan tuntemattomalle kuin siihen perehtyneellekin lukijalle. Vaikka matkailun historiasta on kirjoitettu paljon sekä Suomessa että muualla maailmassa, Rantalan teos on ensimmäinen suomenkielinen yleisesitys, joka käsittelee aihetta nimenomaan 1800luvun alkupuolen näkökulmasta. Rantalan käsittelemä ajanjakso vuodesta 1795 vuoteen 1856 oli liikevoimainen murroskausi matkustamisen kannalta, mutta samalla Euroopassa liikkuivat tiuhaan myös yhteiskunnalliset ja kulttuuriset aatteet sekä valtioiden rajat. Jaksolla riittää tarkastelemattomia aihepiirejä, sillä se on etenkin suomalaisessa historiankirjoituksessa jäänyt pitkään 1800-luvun lopun ilmiöiden varjoon.

Rantala käsittelee teoksessaan matkanteon arkea ja matkustamisen kokemusta ennen modernin turismin aikaa. Aihetta tarkastellaan kahdeksan suomalaisen matkaajan matkapäiväkirjojen, kotiväelle lähetettyjen kirjeiden ja sanomalehdissä julkaistujen matkakertomusten kautta. Mukaan on valikoitunut kaksi naista ja kuusi miestä: kreivitär Sophie Creutz, runoilija ja yliopistomies Frans Michael Franzén, lääkäri ja professori Immanuel Ilmoni, taiteilija Matilda Rotkirch, veljekset Johan Jakob ja Johan Magnus af Tengström, Johan Vilhelm Snellman sekä Zachris Topelius. Heidän kaikkien voi katsoa kuuluneen säätyläistöön ja he kaikki kirjoittivat ruotsiksi. Rantalan teoksen henkilövalintoihin on vaikuttanut se, että aihetta kuvaavaa lähdeaineistoa on säilynyt lähinnä niiltä, joilla oli sekä taitoa että taloudelliset ja sosiaaliset mahdollisuudet kirjoittaa ja jopa julkaista kuvauksia kokemuksistaan. Matkustaminen oli käsitellyllä ajanjaksolla ylipäätään mahdollista enimmäkseen yhteiskunnan etuoikeutetuille. Naiset matkustivat miehiä harvemmin ja säätyläisnaiset useimmiten miesseurassa, mihin tyttärensä ja palvelijattaren kanssa matkustanut kreivitär Creutz (1752-1824) tekee kirjassa poikkeuksen. 
Teoksen varhaisimmat matkailijat, Frans Michael Franzén (1772-1847) ja kreivitär Creutz, aloittivat matkansa modernin kynnyksellä olevaan Eurooppaan Ranskan suuren vallankumouksen jälkeen matkustaen purjelaivoilla ja postivaunuilla. Teoksen myöhäisimmän matkan teki Snellman. Hän matkusti 1850-luvulla, murroksen vuosikymmenellä, aivan massaturismin ja pakettimatkojen aikakauden alussa, jolloin käytettävissä oli höyryvoiman ansiosta myös jo Manner-Euroopan raideverkosto. Vaikka teoksessa esitellyn varhaisimman ja myöhäisimmän matkan väliin mahtuu noin kuusikymmentä vuotta, kaikkia matkalaisia yhdisti matkustaminen Euroopassa, jossa vanhaa poliittista järjestelmää ja sosiaalisia hierarkioita oli horjutettu, ja jossa epävarmuus ja eräänlainen välitila, jonkin uuden odotus näkyi ja tuntui monin tavoin. Euroopan kartassa tapahtunutta konkreettista muutosta on kirjassa havainnollistettu kartoilla vuodelta 1789 ja Wienin kongressin jälkeiseltä ajalta.

Kirjan Suomenlahden rannoilta Sisiliaan asti ulottuneissa matkoissa ei ollut kyse pelkästään huvittelusta vaan ulkomaille veivät uteliaisuuden ja nähtävyyksien lisäksi perheeseen, terveyteen ja työhön liittyvät syyt. Monien matkaajien lähdön motiivina oli sivistys - oppiminen ja suhteiden luominen. Rantala puhuukin 1600- ja 1700-luvun aatelisnuorukaisten kasvatuksellisten grand tour -matkojen perillisistä. Suurin osa matkoista oli nimenomaan kiertomatkoja, ja kirjan teemat etenevätkin luontevasti matkojen vaiheiden mukaan Itämereltä Manner-Euroopan maaseudulle, pikkukaupunkeihin, Alpeille sekä suurkaupunkien vilinään Lontoossa, Berliinissä, Wienissä, Pariisissa ja Roomassa. Ratkaisu edetä temaattisesti niin, että tiettyä aihetta tai paikkaa käsitellään muutaman eri aikaan matkustaneen henkilön kokemusten kautta, on onnistunut etenkin tarinallisuuden ja luettavuuden kannalta. Lukukokemus tuntuu oikealta kiertomatkalta. Haasteena usean eri aikaan matkustaneen kokemusten yhdistymisessä samoihin paikkoihin on, että vuodet ja vuosikymmenet hämärtyvät helposti taustalle. Tämä saattaa paikoitellen tasapäistää tai sekoittaa eri ajankohtiin sijoittuvia ilmiöitä etenkin aikakautta ennestään tuntemattoman lukijan mielessä. Rantalan teksti on kuitenkin sujuvaa, ja lukija huomaa siirtyvänsä kohteesta ja tunnelmasta toiseen enimmäkseen selkeän ja sopivan rauhallisen vaunukyydin tahdissa. Myös kirjan loppuun liitetyt esittelyt kustakin matkaajasta ja näiden matkareiteistä tukevat lukukokemusta tarpeen tullen.

Erilaisia teemoja ja lähestymiskulmia on kirjassa mukana kattavasti. Aikakauden muoti-ilmiöiden, kuten terveysvesiä tarjonneiden kylpylöiden, raunionostalgian sekä Pompeijin ja Herculaneumin arkeologisten kaivausten ohella erilaiset kulkuvälineet saavat oman käsittelynsä, eikä unohdettu ole myöskään matkanteon mahdollistaneita eläinkumppaneita, kuten hevosia ja aaseja, tai muita käytännön yksityiskohtia paikallisaikoineen ja -valuuttoineen. Kaupunkien osalta Rantala on poiminut mukaan arkkitehtuurin ja kulttuurielämysten ohella katuelämää ja erilaisten kaupunkien tunnelmaan johdattavia kuvauksia, joissa näkyvät myös kaupunkien kasvun ja tiivistymisen sekä teollistumisen vaikutukset. Teemojen osalta lukija saattaakin jäädä kaipaamaan lähinnä syventymistä määrän sijaan. Teoksen loppupuolelle sijoitettu luku, jossa Rantala käsittelee erikseen ulkomailla kohdattua erilaisuutta ja vierautta, sekä esimerkiksi kaupunkien pimeää puolta ja inhimillisen kärsimyksen kohtaamista, puolustaa kirjassa paikkaansa. Näiden aiheiden käsittely olisi kuitenkin voinut toimia myös muiden lukujen joukossa. Erillään esittäminen tuntuu ehkä korostavan sitä irrallisuutta, jota joihinkin esitellyistä ilmiöistä muutenkin liitetään. 
Kuten yleisesitysten ja myös suuren yleisön luettavaksi suunnattujen historiateosten kohdalla usein, Rantala on hyödyntänyt lähdemateriaalin osalta jo olemassa olevaa tutkimusta, ja tämä on todennäköisesti vaikuttanut myös kirjaan tehtyihin henkilövalintoihin. Esimerkiksi kreivitär Sophie Creutzin ja taiteilija Mathilda Rotkirchin (1813-1842) kohdalla Rantala on tukeutunut Turun yliopiston kollegojensa, Creutzia laajasti tutkineen Kirsi Vainio-Korhosen ja Rotkirchista pro gradu -tutkielmansa tehneen Topi Artukan tutkimuksiin. Rantala on kuitenkin käynyt läpi runsaasti myös alkuperäisaineistoja ja tehnyt ansiokkaita löytöjä. Hän esittelee esimerkiksi muilta tutkijoilta aiemmin huomaamatta tai ainakin hyödyntämättä jääneen Johan Magnus af Tengströmin (1793-1856) julkaisemattoman matkapäiväkirjan Svenska Litteratursällskapetin arkistosta.

Rantalan teos on kuvitettu aikakauden taiteella ja sellaisella vanhemmalla taiteella, jota kirjan matkaajat ovat matkoillaan päässeet ihailemaan. Lisäksi mukana on Mathilda Rotkirchin matkansa aikana piirtämiä teoksia. Kuvituksen määrä on maltillinen, ja siten se peilaa kuvaamaansa aikakautta ennen valokuvia ja niiden yleistymistä, jolloin ennakkomielikuvat vieraista paikoista luotiin visuaalisten esitysten sijaan enimmäkseen kirjallisesti. Kirjallisuus liittyi matkustamiseen hyvin kiinteästi erilaisina oppaina, ohjeina, viittauksina ja esikuvina, ja tämä näkyy hienosti myös kirjaan tehdyissä valinnoissa. Runsaat suorat lainaukset alkuperäislähteistä rytmittävät tekstiä, ja mukana on helmiä, joiden myötä lukijassa herää halu tutustua kohteeseen tai ilmiöön tarkemmin itsekin. Näin teoksen voi omalla tavallaan ajatella myös jatkavan matkakirjallisuuden ja opaskirjojen perintöä.

Siinä missä kirjan matkaajat ovat ajoittain kokeneet vaikeaksi kertoa kaikesta näkemästään ja kuulemastaan, valitellen kuvauksensa epätarkkuutta tai joutuen toteamaan koetun olleen yksinkertaisesti mahdoton pukea sanoiksi jopa kotona matkakirjeitä odotteleville aikalaisille, nykypäivän lukijan etäisyys heidän kokemuksiinsa voi tuntua erityisen pitkältä. Rantala on kuitenkin onnistunut kaventamaan tuota etäisyyttä paitsi hyvällä kontekstoinnilla, myös valikoimalla kirjaan lukuisia sellaisia lainauksia ja yksityiskohtia, joiden kautta lukija voi eläytyä matkatunnelmiin eri aistien kautta. Parhaimmillaan lähdeaineistosta nostetun yksityiskohdan voi myös aivan konkreettisesti kokea. Toisin kuin aikalainen matkakirjeen vastaanottaja, nykypäivän lukija voi helposti laittaa soimaan esimerkiksi viulistivirtuoosi Paganinin säveltämää musiikkia tai Gregorio Allegrin 1600-luvulla paavin kuorolle säveltämän teoksen, joista vuosina 1828-1830 Euroopassa matkustanut Immanuel Ilmoni (17971856) matkakuvauksessaan kertoo. Se, että Rantala on avannut näitä aineistosta löytyneitä pieniäkin "johtolankoja" syvällisesti, avaa uusia näkymiä myös aikakautta tuntevalle lukijalle.

Kirjan ensimmäisten matkojen aikaan Suomen alue oli vielä osa Ruotsin kuningaskuntaa, mutta 1840- ja 1850-luvuille tultaessa Suomi oli Venäjän alaisena suuriruhtinaskuntana ehtinyt muotoutua monella tapaa toisenlaiseksi. Kirjan matkaajien kautta avautuukin ulkomaiden ohella näkymä myös Suomeen ja erilaisiin, muuttuviin "suomalaisuuksiin". Kuten matkakuvaukset usein, myös Rantalan valitsemat tekstit tulevat vierasta kuvatessaan paljastaneeksi yhtä ja toista myös kirjoittajiensa kotimaan kulttuurista, tavoista, arvoista ja arvostuksista. Välimatkan Suomesta Eurooppaan voi teoksen perusteella todeta olleen 1800-luvun alkupuolella sekä pitkä että lyhyt. Fyysinen matka oli kaikille viikkojen mittainen, mutta henkisen matkan pituus riippui ennen kaikkea kokijan sosiaalisesta asemasta ja säädystä. Vaikka monet 
aikakauden suomalaiset liikkuivat Euroopassa ja myös muualla maailmassa, matkustamista ilmensi 1800-luvun alkupuolella vielä vahvasti sen harvinaisuus. Tuo harvinaisuus erottaa Rantalan mukaan ajan matkustamisen kenties merkittävimmin nykypäivästä, mutta koronapandemia on kirjan ilmestymisen jälkeen tuonut tähänkin uutta katsantokulmaa. Ehkä olemme hiljentyneiden terminaalien myötä aavistuksen verran lähempänä kirjan matkaajien kokemuksia, ja aikamme epävarmuudessa kaikuu samankaltaisia tunteita muutoinkin. Myös niin sanotusta hitaasta matkailusta kiinnostuneille Pikisaaresta Pariisiin on inspiroiva kirja. Se muistuttaa matkan kokemuksen kokonaisvaltaisuudesta, hyvine ja huonoine hetkineen kaikkineen.

Heidi Pitkänen

FM, Suomen historia, Turun yliopisto

hmpitk (apud) utu.fi 